\title{
New Aspects on Atrazine Biodegradation
}

\author{
Luciane Sene $^{1 *}$, Attilio Converti ${ }^{2}$, Geslaine Aparecida Ribeiro Secchi ${ }^{1}$ and Rita de Cássia \\ Garcia Simão \\ ${ }^{1}$ Centro de Ciências Médicas e Farmacêuticas; Universidade Estadual do Oeste do Paraná; Rua Universitária \\ 2069; Cascavel - PR - Brasil. ${ }^{2}$ Facoltà di Ingegneria; Dipartimento di Ingegneria Chimica e di Processo; \\ Università degli Studi di Genova; Via dell'Opera Pia 1; I-16145; Genoa - Italy
}

\begin{abstract}
The world practice of using agrochemicals for long periods, in an indiscriminated and abusive way, has been a concern of the authorities involved in public health and sustainability of the natural resources, as a consequence of environmental contamination. Agrochemicals refer to a broad range of insecticides, fungicides and herbicides, and among them stands out atrazine, a herbicide intensively used in sugarcane, corn and sorghum cultures, among others. Researches have demonstrated that atrazine has toxic effects in algae, aquatic plants, aquatic insects, fishes and mammals. Due to the toxicity and persistence of atrazine in the environment, the search of microbial strains capable of degrading it is fundamental to the development of bioremediation processes, as corrective tools to solve the current problems of the irrational use of agrochemicals. This review relates the main microbial aspects and research on atrazine degradation by isolated microbial species and microbial consortia, as well as approaches on the development of techniques for microbial removal of atrazine in natural environments.
\end{abstract}

Key words: atrazine, biodegradation, bacteria, fungi, microbial consortium

\section{INTRODUCTION}

Atrazine [2-chloro-4-(ethylamino)-6(isopropylamino)-s-triazine] is a selective herbicide belonging to the family of the striazines, which contains in its chemical structure an aromatic hexameric and symmetrical ring constituted by three carbon and three nitrogen atoms in alternate positions (Fig. 1). Atrazine is worldwide used, often in combination with other herbicides (Chan \& Chu, 2005), to control broadleaf and grassy weeds in agriculture, especially in corn, sorghum and sugar cane crops and in conifer reforestation planting (Ribeiro et al., 2005). Atrazine kills susceptible plants by binding to the quinone-binding protein in photosystem II, thus, inhibiting the photosynthetic electron transport.

Atrazine is a pollutant of environmental concern due to its low biodegradability and its high potential to contaminate the surface waters and groundwater (Chan \& Chu, 2005). Although it is a banned or regulated substance in several countries, $100 \mathrm{ng}^{-1}$ to $1 \mu \mathrm{g}^{-1}$ concentrations have been reported in surface waters (Parra et al., 2004).

Once in aquatic environment, atrazine may alter the structure and function of the communities. Standard toxicity tests performed on five microalgal species of different taxonomic families revealed differential sensitivity to atrazine exposure. Species listed in order of increasing sensitivity were: Isochrysis galbana, Dunaliella

*Author for correspondence: 1sene@unioeste.br 
tertiolecta, Phaeodactylum tricornutum, Pseudokirchneriella subcapitata and Synechococcus sp. (Weiner et al., 2004). Comparing the acute toxicity of 40 herbicides exerting nine different modes of action on the green alga Raphidocelis subcapitata, Ma et al. (2006) found that photosynthesis was the most sensitive process, and atrazine was among the most toxic herbicides tested.<smiles>CCNc1nc(Cl)nc(NC(C)C)n1</smiles>

Figure 1 - Chemical structure of atrazine.

Triazinic compounds such as atrazine, simazine, propazine, as well their metabolites, mainly 2hydroxyatrazine, diaminochlorotriazine, deethylatrazine and deisopropylatrazine, were shown to induce mammary gland tumors in Sprague-Dawley (SD) female rats (Stevens et al., 1994). Atrazine has also been suggested to be a potential disruptor of normal sexual development in male frogs (Hayes et al., 2002; Murphy et al., 2006) as well as to alter some aspects of the immune response (Christin et al., 2004). In 2007, the United States Environmental Protection Agency (USEPA) began reviewing several epidemiological cancer studies concerning atrazine and its possible association with carcinogenic effects in humans.

Although atrazine has toxic effects on life, its metabolites, including deethylatrazine and deisopropylatrazine, are currently assumed to be less toxic than their parent (Kross et al., 1992; EPA 2002). However, especially in agricultural soils, deethylatrazine and deisopropylatrazine, which retain the chlorine atom, are considered phytotoxic (Honout et al., 1998).

\section{Biodegradation of atrazine}

Atrazine is considered persistent due to its moderate water solubility $\left(33 \mathrm{mg}^{-1}\right.$ at $\left.20^{\circ} \mathrm{C}\right)$ and low soil sorption partition coefficient $\left(K_{\mathrm{d}}=3.71\right.$ $\left.\mathrm{kg}^{-1}\right)$. Although the halogen, methylthioether, and $\mathrm{N}$-alkyl substituents on the s-triazine ring of this group of herbicides hinder the microbial metabolism (Wackett et al., 2002), some reports have demonstrated the ability of some soil microorganisms to degrade atrazine partially or totally directing it to carbon dioxide and ammonia formation (Mandelbaun et al., 1995; Rosseaux et al., 2003; Sing et al., 2004a).

The biodegradation of atrazine in soil is space variable, being slower in subsurface zones than in surface soil. Under vadose zone and subsurface aquifer conditions, low temperatures and the lack of degrading organisms are likely to be primary factors limiting its biodegradation (Radosevich $e t$ al., 1996).

The research on atrazine-degrading microrganisms has been directed to the isolation and characterization of natural occurrence lineages in environments contaminated with this pesticide. According to Rhine et al. (2003), the repeated exposure to atrazine can increase biodegradation, which may be also enhanced as a result of limited $\mathrm{N}$ availability. Fang et al. (2001) observed that the number of atrazine degrading bacteria did not alter significantly prior to atrazine exposure, but significantly reduced the acclimation period preceding the onset of mineralization. Silva et al. (2004) demonstrated the occurrence of fast atrazine mineralization after an acclimatization period of approximately 28 days.

\section{Atrazine degradation by bacteria}

Among bacteria, there are reports on atrazine degradation by individual strains such as Pseudomonas sp. (Mandelbaum et al., 1995; Katz et al., 2001), Rodococcus rhodochrous (Jones et al., 1998), Acinetobacter spp. (Singh et al., 2004a), Aerobacterium sp., Microbacterium sp., Bacillus sp., Micrococcus sp., Deinococcus sp. and Delftia acidovorans (Vargha et al., 2005), as well as by species consortia including Agrobacterium tumefaciens, Caulobacter crescentus, 
Pseudomonas putida, Sphingomonas yaniokuyae, Nocardia sp., Rhizobium sp., Flavobacterium oryzihabitans and Variovorax paradoxus (Smith et al., 2005). Pseudomonas sp. ADP, isolated from soil contaminated with atrazine, was shown to mineralize completely the triazinic ring (Mandelbaum et al., 1995). Sing et al. (2004a) isolated a bacterium member of Acinetobacter genus capable of degrading atrazine as a carbon source at concentration as high as $250 \mathrm{ppm}$. In granular activated carbon column filters inoculated with $R$. rhodochrous, atrazine degradation achieved $72.6 \%$ after 39 days (Jones et al., 1998). The strain D. acidovorans D24 mineralized atrazine as a sole source of carbon and nitrogen (Vargha et al., 2005).

The atrazine degrading bacteria generally initiate the degradation through a hydrolytic dechlorination, catalysed by the enzyme atrazine chlorohydrolase (AtzA), encoded by the atzA gene, followed by two hydrolytic deamination reactions catalysed by hydroxy-atrazine ethylamino-hydrolase (AtzB) and $\mathrm{N}$-isopropylammelide isopropyl-amino-hydrolase (AtzC), encoded by the genes $\operatorname{atz} B(\operatorname{trz} B)$ e $a t z C(t r z C)$, respectively (De Souza et. al., 1996; De Souza et. al., 1998a; Sadowsky et al., 1998), which convert atrazine sequentially to cyanuric acid that is then completely mineralized to $\mathrm{CO}_{2}$ and $\mathrm{NH}_{3}$ by other three hydrolases. In some bacterial strains the biodegradation of atrazine initiate through $\mathrm{N}$ dealkylation of the lateral ethyl and isopropyl chains to deethylatrazine and deisopropylatrazine (Kaufman and Blake, 1970) (Fig. 2).

Pseudomonas sp. ADP is the best-characterized bacterial strain capable to degrading the herbicide atrazine. The atrazine catabolic pathway in this bacterium contains six enzymatic steps encoded by $a t z A B C$ and the atzDEF genes. The atzABC genes have been shown to be widespread and plasmid borne in a number of bacteria isolates (de Souza et al., 1998a; de Souza et al., 1998b; Rousseaux et al., 2001; Topp et al., 2000; Wackett et al., 2002). In Pseudomonas sp. ADP, the atzABCDE genes are harbored on the catabolic plasmid pADP-1 (Martinez et al., 2001).

In Pseudomonas sp. ADP, the atzDEF operon encodes cyanuric acid amidohydrolase (AtzD), biuret amidohydrolase (AtzE), and allophanate hydrolase (AtzF), involved in cleavage of the cyanuric acid to carbon dioxide and ammonia, which is assimilated as a nitrogen source (de
Souza et al., 1998a). García-González et al. (2003) have demonstrated that atrazine catabolism is induced under nitrogen-limited growth in a manner reminiscent of general nitrogen control in Pseudomonas sp. ADP.

The atz $A B C$ genes are constitutively expressed and are not regulated either by induction of atrazine or by repression of other $\mathrm{N}$ sources in this strain (Martínez et al., 2001; Devers et al., 2004). The atzDEF genes are divergently transcribed from AtzR, predicted to encode a transcriptional LysRtype regulator. A putative LTTR binding site can in fact be found upstream of $a t z D$ gene, thereby suggesting that transcription of the atzDEF operon may be regulated and the protein encoded by the orf99 (AtzR) play a role in this regulation. The $a t z D E F$ operon resides in a contiguous cluster adjacent to the orf99, a potencial LysR-type transcriptional regulator (Martínez et al., 2001).

In order to analyze the regulation of the expression of atzDEF genes, atzD-lacZ and atzR-lacZ transcriptions fusions were obtained, and the $\beta$ galactosidase assay was performed by GarcíaGonzález et al. (2005). Expression of the cyanuric acid degradation atzDEF operon is specifically induced by cyanuric acid. The AtzR regulator activates the expression of atzDEF operon in the presence of cyanuric acid and represses its own synthesis. The expression of the $a t z R$ gene was also induced by nitrogen limitation and repressed by AtzR. Nitrogen regulation of atzD-lacZ and $a t z R$-lac $Z$ expression was dependent on the alternative sigma factor $\sigma^{\mathrm{N}}$ and $\mathrm{NtrC}$ (activator of $\sigma^{\mathrm{N}}$ promoters), hence suggesting that the cyanuric acid degradation operon may be subject to general nitrogen control. However, atzDEF transcription appears to be driven by the major sigma factor $\sigma^{70}$, while $a t z R$ is transcribed from a $\sigma^{\mathrm{N}}$ dependent promoter. In fact, the atzR-lacZ was almost abolished in an $\operatorname{rpoN}\left(\sigma^{\mathrm{N}}\right)$ mutant. Expression of $a t z R$ from a heterologous promoter revealed that although $\mathrm{NtrC}$ regulation of $a t z D$-lac $Z$ requires the AtzR protein, it is not the indirect result of NtrCactivated AtzR synthesis. AtzR activity is in turn modulated by the presence of cyanuric acid and by a nitrogen limitation signal transduced by the Ntr system. The mechanism for $\mathrm{NtrC}$ mediated activation of atzDEF expression has been not yet identified (García-González et al., 2005). The effect of nitrogen on the herbicide degradation pathway is strongly relevant to the use of this strain in bioremediation, since many agricultural 
fields are rich in nitrogen owing to routine fertilization.

Pseudomonas sp. ADP is able to degrade atrazine as a sole nitrogen source and can also grow using phenol as the carbon source. Genes encoding phenol degradation are located on its chromosome.
A multicomponent phenol hydroxylase converts phenol to catechol, which is further metabolized via ortho pathway using catechol 1,2-dioxygenase (Neumann et al., 2004). The strain was stimulated to degrade high concentrations of phenol $(1,000$ $\left.\mathrm{mg}^{-1}\right)$ and atrazine $\left(150 \mathrm{mg} \mathrm{l}^{-1}\right)$ simultaneously.

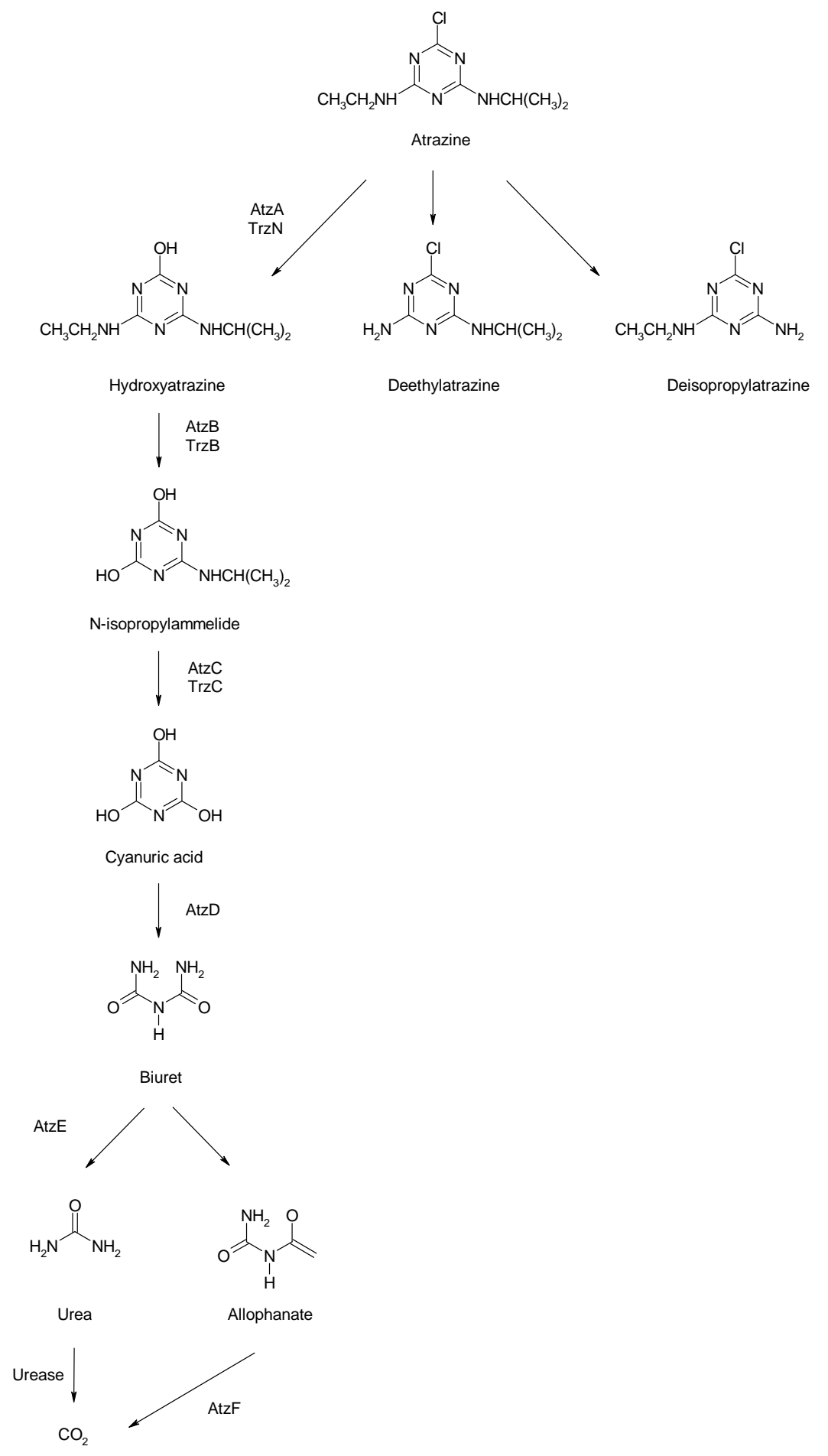

Figure 2 - Atrazine degradation pathways in bacteria 
Whereas atrazine did not show any significant toxic effects on the cell, phenol reduced growth and activated or induced typical membraneadaptive responses known for the genus Pseudomonas, just to name a few, changes in the fatty acid composition of membrane lipids and isomerization of cis-unsaturated fatty acids to trans-unsaturated fatty acids (Heipieper et al., 1992; von Wallbrunn et al., 2003). This showed that Pseudomonas sp. ADP could be usefully employed in the study on the regulatory interactions among the catabolic genes and stress response mechanisms during the simultaneous degradation of toxic phenolic compounds and a xenobiotic $\mathrm{N}$ source such as atrazine.

The ability to degrade atrazine by using the products of atzABCDEF is not an exclusivity of the Pseudomonas genus. Recently, a strain CDB21 was identified as a novel $\beta$-proteobacterium exhibiting $100 \%$ sequence identity with the uncultured bacterium HOCLCi25 (GenBank accession number AY328574). CDB21 also possesses the entire set of genes of atrazine degradation present in Pseudomonas (Iwasaki et al., 2007). The nucleotide sequences of the atzABCDEF genes of strain CDB21 were $100 \%$ identical to those of Pseudomonas sp. ADP, which suggested a dispersal of the atz genes in the environment. According to this, studies revealed that $a t z A B C$ genes were widespread, having been detected in Canada, U.S.A., France, Croatia and China, and were also highly conserved (>97\% similarity) indicating their recent dispersion within soil microflora (de Souza, 1998a; Rosseaux et al., 2001; Devers et al., 2004).

Devers et al. (2005) demonstrated that the atrazine-degrading plasmid ADP1::Tn5 was transferred from Agrobacterium tumefaciens St964 to soil microflora at a frequency of $10^{-4}$ per donor cell. In two of the gram-negative transconjugants isolated, namely Variovorax $\mathrm{sp}$. MD1 and MD2, the $a t z A$ and $a t z B$ genes had moved from pADP1::Tn5 to the chromosome. A recent study demonstrated for the first time the involvement of the insertion sequence IS1071 in the transposition of catabolic genes (Devers et al., 2007). These authors also suggested that $I S$ mediated transposition of the atz genes could also be indirectly involved. Indeed, such rearrangements led to diversification of the atz genetic supports and could contribute to increase the frequency of horizontal gene transfer (HGT) of the atz genes.
According to Ostrofsky et al. (2002), the gene trzD, present in Pseudomonas NRRLB-12228, was involved in s-triazinic ring cleavage, and was not dominant among atrazine degrading population in soil. The Chelatobacter heintzii Citl, that showed the capacity to mineralize up to $80 \%$ of atrazine in 14 days, possessed the atrazine degrading genes $a t z A B C$ and $\operatorname{trz} D$ (Rousseaux et al., 2003). According to Piutti et al. (2003), Nocardioides sp. SP12 utilized a different degradation pathway combining the genes $\operatorname{trz} N$, which codified a chlorohydrolase, with $a t z B$ and $a t z C$, leading to a product with the same characteristics as the cyanuric acid (Fig. 2). Arthrobacter sp. strain isolated from the rhizosphere of atrazine-resistant plant by Vaishampayan et al. (2007) utilized atrazine as the sole nitrogen source and harbours $a t z B C D$ and $t r z N$ on chromosomal DNA with high sequence similarity with $\operatorname{trz} N$ from Nocardioides sp. C190.

Little is known about the biodegradability of atrazine under anoxic and methanogenic conditions in soils. In anaerobic systems, atrazine is more resistant to degradation, with the half-life values varying from 160 to 330 days ( $\mathrm{Gu}$ et. al., 2003). However, Pseudomonas sp. ADP was shown to mineralize more than $50 \%$ of $2.8 \mu \mathrm{M}$ atrazine within 14 days under both aerobic and denitrifying conditions (Clausen et al., 2002). The bacterium M91-3 was able to use atrazine as the sole carbon and nitrogen source under anoxic conditions leading to hydroxytriazine and triazinic ring cleavage between $\mathrm{C}-2$ and $\mathrm{N}$. These results suggested a possible application of this bacterium in a fixed bed reactor for anaerobic removal of atrazine and nitrate from water (Crawford et al., 1998).

In a laboratory scale system for the treatment of Danube river water, the main atrazine metabolite was hydroxyatrazine (Vargha et al., 2005). Atrazine utilizing strains isolated from sediment showed diverse atrazine metabolism leading to ammeline and ammelide products. Because dealkylated and dechlorinated metabolites are more easily degraded than atrazine and hydroxyatrazine, subsequent mineralization could be performed by an adapted microbial consortium.

\section{Atrazine degradation by microbial consortia}

The biotic degradation of atrazine can follow several metabolic pathways that involve stepwise transformations mediated by single species or microbial consortia. Although several atrazine- 
degrading bacteria have been isolated and their individual catabolic pathways extensively studied, the cooperative metabolism of atrazine is yet poorly described.

In a microbial consortium, after the dechlorination of atrazine by Nocardia sp., the resulting hydroxyatrazine was afterwards degraded in two different ways. In one of them, Nocardia sp. converted hydroxyatrazine to $\mathrm{N}$-ethylammelide via an unidentified gene product, whereas in the other, hydroxyatrazine generated by Nocardia sp. was hydrolyzed to $\mathrm{N}$-isopropylammelide by Rhyzobium sp., which contained the gene atzB. All the members of the consortium contained $a t z C$, responsible for the cleavage of the ring, besides the gene $\operatorname{tr}_{z} D$. However, none of the microorganisms showed to carry atzD, $E$ or $F$ genes (Smith et al., 2005).

Kolic et al. (2007) characterized a four-member atrazine-mineralizing community enriched from an agrochemical factory soil, which was capable of rapidly mineralizing atrazine (approx. $78 \%$ of atrazine was released as ${ }^{14} \mathrm{CO}_{2}$ within 6 days). The analysis of the genetic potential of individual community members reveled that two Arthrobacter strains, named ATZ1 (carrying trzN and $a t z C$ genes) and ATZ2 (carrying $\operatorname{trz} N, a t z B$ and $a t z C$ genes) might be involved in the upper pathway producing cyanuric acid, and that other two members, Ochrobactrum sp. CA1 and Pseudomonas sp. CA2 (both carrying $\operatorname{trz} D$ gene), were responsible for cyanuric acid catabolism.

The physical and chemical associations of microbial community members in biofilms lead to interactions at the genetic level intra and interspecies. Some bacteria in contaminated environments are in fact submitted to genetic events, such as transformation, transduction and conjugation, thus acquiring improved abilities to degrade hazardous substrates (Stoodley et al., 2002). Perumbakkan et al. (2006) demonstrated that it was possible to modify the microbial biofilms through natural transformation in order to improve their biodegradation capabilities. These authors transformed biofilm communities with the gene $a t z A$ that encoded atrazine chlorohydrolase. Both kinds of biofilms communities, pure and soilderived cultures, were transformed with atzA gene cloned in the broad host plasmid pBBR1NCSS, and all of them displayed the ability to degrade atrazine. These results suggested that the natural transformation should be useful as a tool to enhance bioremediation process performed by biofilms.

\section{Atrazine degradation by fungi}

The degradation of atrazine was also observed in fungi such as Aspergillus fumigatus, Aspergillus ustus, Aspergillus flavipes, Rhizopus stolonifer, Fusarium moniliforme, Fusarium roseum, Fusarium oxysporum, Penicillium decumbens, Penicillium janthinellum, Penicillium rugulosum, Penicillium luteum, Trichoderma viride. It proceeds through N-dealkylation of either alkylamino group; however, with qualitative and quantitative differences, leading to two main degradation products, deethylatrazine and deisopropylatrazine (Kaufman and Blake, 1970).

The potential of the white-rot fungi to perform in situ bioremediation has been ascribed to their ability to degrade a variety of xenobiotic chemicals via free radical mechanism mediated by extracellular peroxidases (Reddy, 1995). Degradation of atrazine by the white-rot fungus Phanerochaete chrysosporium was demonstrated by a $48 \%$ decrease of the initial herbicide concentration in the growth medium within the first 4 days of incubation. Results point out $25 \%$ mineralization of the ethyl group of the herbicide and the formation of hydroxylated and/or Ndealkylated metabolites; however, no mineralization of ring-14C-labeled atrazine was observed (Mougin et al., 1994). In non-sterile soil samples amended with the same white-rot fungus in the presence of wood chips, atrazine was mineralized especially in summer, spring and fall (Entry et al., 1996). Pleurotus pulmonarius is another lignocellulolytic fungus that has been found to degrade atrazine in liquid culture, producing mainly the $\mathrm{N}$-dealkylated metabolites deethylatrazine, deisopropylatrazine and deethyldeisopropylatrazine and the hydroxypropyl metabolite hydroxyisopropylatrazine (Masaphy et al., 1993). In a solid medium based on a mixture of cotton and wheat straw, $P$. pulmonarius was not capable of mineralize the triazinic ring, being part of atrazine adsorbed to the straw, and another portion transformed into either chlorinated or dechorinated atrazine metabolites, as the result of the activity of both the fungus inoculated and the natural bacterial population (Masaphy et al., 1996a). Manganese concentrations up to $300 \mu \mathrm{M}$ enhanced atrazine transformation by this fungus with accumulation of both N-dealkylated and 
propylhydroxylated metabolites, probably due to an increase in non specific oxidative activities involved in the transformation of xenobiotic compounds (Masaphy et al., 1996b).

\section{Strategies for microbial removal of atrazine}

The technique of bioaugmentation, that is, addition of natural microbial strains or genetically engineered variants to decontaminate polluted soil, is a strategy often utilized when low biodegradation is detected in the contaminated site. Rousseaux et al. (2003) observed that the introduction of $10^{4} \mathrm{UFC}^{-1}$ of Chelatobacter heintzii Cit 1 in soil poorly mineralizing atrazine resulted in a 3-fold increase in such a capacity. Gupta \& Baummer (1996) studied the effect of poultry litter, commonly applied to the soil as manure before the utilization of atrazine, on the biodegradation of atrazine and verified that the rate of atrazine removal in soil was two times faster than without the litter; nutrients (mainly nitrates and phosphates) present in litter did not play any role in the degradation of atrazine.

In a field-scale remediation study of a soil contaminated by an accidental spill of atrazine (up to $29,000 \mathrm{ppm}$ ), bioaugmentation was performed using a killed and stabilized whole-cell suspension of recombinant $E$. coli engineered to overproduce atrazine chlorohydrolase, AtzA. After eight weeks, atrazine levels declined by $52 \%$ in plots containing killed recombinant $E$. coli cells, whereas $77 \%$ biostimulation was detected in plots that received $300 \mathrm{ppm}$ of phosphate (Strong et al., 2000). Cell-free crude extracts from Pseudomonas sp. ADP containing the enzymes that catalyzed atrazine degradation were entrapped in sol-gel glass; however, there was a significant loss of activity in comparison with the non-entrapped crude extract (Kauffmann \& Mandelbaum, 1996). This strategy could be only a promising alternative for the bioremediation of atrazine, since the consequences of release of engineered live cells to the environment are already unknown.

Bioaugmentation with Pseudomonas sp. ADP together with citrate or succinate biostimulation markedly increased atrazine mineralization in a soil that had an indigenous potential for atrazine biodegradation (e.g., addition of $11.6 \mathrm{mg}$ of citrate per $\mathrm{g}$ of soil increased mineralization of $337.4 \mu \mathrm{g}$ of atrazine per $\mathrm{g}$ of soil from $<2$ to $79.9 \%$ in 13 days) (Silva et al., 2004). Cellulose substantially stimulated atrazine side-chain dealkylation by soil microflora in comparison with other carbon- containing substrates, being the rate and extent of mineralization of the ethylamino side chain significantly accelerated by a decrease in the $\mathrm{C} / \mathrm{N}$ ratio of the amendment. Glucose release or a transient production of glucose as an end-product of cellulose depolymerization might induce the catabolic repression of dealkylation enzyme systems and be responsible for a decrease in the atrazine side-chain mineralization (Yassir et al., 1998). The biodegradation of atrazine by an anaerobic mixed culture was higher in cometabolic process than in the absence of external carbon source or carbon and nitrogen source (firstorder degradation rates of $5.5 \times 10^{-4}, 2.5 \times 10^{-5}$ and $1.67 \times 10^{-5}$ day $^{-1}$ respectively), being maximum atrazine degradation observed in a medium composed of $300 \mathrm{mg} \mathrm{l}^{-1}$ of dextrose and $5 \mathrm{mg} \mathrm{l}^{-1}$ of atrazine.

As most atrazine-degrading bacteria use this herbicide as a nitrogen source, the presence of preferential nitrogen sources in the environment is detrimental to atrazine degradation. Nitrogen amendments were in fact shown to decrease atrazine degradation rates by Pseudomonas sp. ADP (Clausen et al., 2002; García González et al., 2003). In fungi, nitrogen suppressed mineralization of atrazine but stimulated the primary growth, thereby suggesting that $\mathrm{N}$ could alter the microbial processes and $\mathrm{C}$ uptake and thus influence the rates of herbicide degradation (Entry et al., 1993).

In rhizosphere soil, an increased degradation of xenobiotic compounds may result from cometabolic processes enhanced by organic substances originating from roots exudates with an overall increase in microbial activity (Fang et al., 2001). Atrazine was degraded faster in contaminated soil planted with Pennisetum (Pennisetum clandestinum) than in unplanted soil, corresponding to nearly 45 and $22 \%$ respectively within 80 days (Singh et al., 2004b). Contrarily, it was not so for atrazine degradation in grass rhizosphere (Fang et al., 2001).

\section{Final remarks}

This review highlights the main microbial aspects of atrazine degradation, focusing its catabolism by indigenous and engineered microorganisms as well as the effects resulting from biostimulation and bioaugumentation. An overview of these aspects reveals that the complete mineralization of atrazine is possible as a result of the microbial activity. Since a deep knowledge of the microbial 
activity and its implementation in the engineering area are the basis for the expansion of the use of bioremediation systems, the remediation of natural environments contaminated with this herbicide is expected to be accomplished in the near future.

\section{RESUMO}

A prática mundial do uso de agroquímicos por períodos extensos, de maneira indiscriminada e abusiva, tem mobilizado as autoridades envolvidas em saúde pública e sustentabilidade de fontes naturais, como uma consequiência da contaminação ambiental. Agroquímicos referemse a uma ampla variedade de inseticidas, fungicidas e herbicidas, entre estes a atrazina, um herbicida intensivamente usado em culturas de cana-de-açúcar, milho, sorgo, entre outros. Pesquisadores têm demonstrado que a atrazina tem efeitos tóxicos em algas, plantas aquáticas, insetos aquáticos, peixes e mamíferos. Devido à toxicidade e à persistência da atrazina no ambiente, a busca de linhagens microbianas capazes de degradá-la é fundamental para o desenvolvimento de processos de biorremediação, com uma ferramenta corretiva para solucionar problemas decorridos do uso irracional de agroquímicos. Esta revisão relata os principais aspectos microbianos e pesquisas da degradação da atrazina por espécies microbianas isoladas e consórcio microbiano, bem como avanços no desenvolvimento de técnicas para remoção microbiana da atrazina no ambiente natural.

\section{REFERENCES}

Chan, K.H. and Chu, W. (2005), Atrazine removal by catalytic oxidation processes with or without UV irradiation Part II: an analysis of the reaction mechanisms using LC/ESI-tandem mass spectrometry. Appl. Catalysis B: Environ., 58, 165174.

Christin, M.S., Menard, L., Gendron, A.D., Ruby, S., Cyr, D., Marcogliese, D.J., Smith, L.R., Fournier, M. (2004), Effects of agricultural pesticides on the immune system of Xenopus laevis and Rana pipiens. Aquat. Toxic., 6, 33-43.
Clausen, G.B., Larsen, L., Johnsen, K., Lipthay, J. R. de, Aamand, J. (2002), Quantification of the atrazinedegrading Pseudomonas sp. strain ADP in aquifer sediment by quantitative competitive polymerase chain reaction. FEMS Microbiol. Ecol., 41, 211 - 229.

Crawford, J.J., Sims, G.K., Mulvaney, R.L. Radosevich, M. (1998), Biodegradation of atrazine under denitrifying conditions. Appl. Microbiol. Biotechnol., 25, 618 - 623.

de Souza, M. L., J. Seffernick, B. Martinez, M. J. Sadowsky, and L. P. Wackett. (1998a), The atrazine catabolism genes $a t z A B C$ are widespread and highly conserved. J. Bacteriol., 180, 1951-1954.

de Souza, M. L., Wackett, L. P. and Sadowsky, M.J. (1998b), The atzABC genes encoding atrazine catabolism are located on a self-transmissible plasmid in Pseudomonas sp strain ADP. Appl. Microbiol. Biotechnol., 64, 2323-2326.

de Souza, M.L., Sadowsky, M.L., Wackrtt, L.P. (1996), Atrazine chlorohydrolase from Pseudomonas sp. strain ADP: gene sequence, enzyme purification and protein characterization. J. Bacteriol., 178, 48944900.

Devers, M., Soulas, G., Martin-Laurent, F. (2004), Real-time reverse transcription PCR analysis of expression of atrazine catabolism genes in two bacterial strains isolated from soil. J. Microbiol. Meth., 56, 3-1.

Devers, M., Henry, S., Hartmann, A., Martin-Laurent, F. (2005), Horizontal gene transfer of atrazinedegrading genes (atz) from Agrobacterium tumefaciens St96-4 pADP1::Tn5 to bacteria of maizecultivated soil. Pest Manag. Sci., 61, 870-880.

Devers, M., Rouard, N. and Martin-Laurent, F. (2007), Genetic rearrangement of the $a t z A B$ atrazinedegrading gene cassette from pADP1::Tn5 to the chromosome of Variovorax sp. MD1 and MD2. Gene, 392, 1-6.

Entry, J.A., Donnelly, P.K., Emmingham, W.H. (1996), Mineralization of atrazine and 2,4-D in soils inoculated with Phanerochaete chrysosporium and Trappea darkeri. Appl. Soil Ecol., 3, 85 - 90.

Entry, K., Mattson, G. Emmingham, W.H. (1993), The influence of nitrogen on atrazine and 2,4dichlorophenoxyacetic acid mineralization in grassland soils. Biol. Fert. Soils, 16, 179-182.

Fang, C., Radosevich, M., Fuhrmann, J.J. (2001), Atrazine and phenanthrene degradation in grass rhizosphere soil. Soil Biol. Biochem., 3, 671-678.

García-González, V., Porrua, O. and Santero, E. (2005), Regulation of the Pseudomonas sp. strain ADP cyanuric acid degradation operon. J. Bacteriol., 187, 155-167. 
García-González, V., Govantes, F., Shaw, L.J., Burns, R.G., Santero, E. (2003), Nitrogen control of atrazine utilization in Pseudomonas sp. strain ADP Appl. Environ. Microbiol., 69, 6987 - 6993.

Gu, J.G., Fan, Y., Gu, J. D. (2003), Biodegradability of atrazine, cynazine and dicamba under methanogenic condition in three soils of China. Chemosph., 52, 1515-1521.

Gupta, G. \& Baummer III, J. (1996), Biodegradation of atrazine in soil using poultry litter. J. Haz. Materials, 45, 185 - 192.

Hayes, T.B., Collins, A., Lee, M., Mendoza, M., Noriega, N., Stuart, A.A. and Vonk, A. (2002), Hermaphroditic, demasculinized frogs after exposure to the herbicide atrazine at low ecologically relevant doses. Proc. Natl. Acad. Sci. USA, 99, 5476-5480.

Heipieper,H., Diefenbach, R. and Keweloh, H. (1992), Conversion of cis-unsatured fatty acids to trans, a possible mechanism for the protection of phenoldegrading Pseudomonas putida P8 from substrate toxicity. Appl. Environ. Microbiol., 58, 1847-1852.

Hounout, S., Barriuso, E., Berheaud, V. (1998), Modifications to atrazine degradation pathways in a loamy soil after the addition of organic amendments. Soil Biol. Biochem., 30, 2147 - 2157.

Iwasaki, A., Takagi, K., Yoshioka, Y., Fuji, K., Kojima, Y., Harada, N. (2007), Isolation and characterization of a novel simazine-degrading beta-proteobacterium and detection of genes encoding s-triazine-degrading enzymes. Pest Manag. Sci., 63, 261-268.

Jones, L.R., Owen, S.A., Horrell, P., Burns, R.G. (1998), Bacterial inoculation of granular activated carbon filters for the removal of atrazine from surface water. Wat. Res., 32, 2542 - 2549.

Katz, I., Dosoretz, C.G., Mandelbaum, R.T., Green, M. (2001), Atrazine degradation under denitrifying conditions in continuous culture of Pseudomonas ADP. Wat. Res., 35, 3272 - 3275.

Kauffmann, C.G., Mandelbaum, R. T. (1996), Entrapment of atrazine-degrading enzymes in sol-gel glass. J. Biotechnol., 51, 219-225.

Kaufman, D.D. and Blake, J. (1970), Degradation of atrazine by soil fungi. Soil Biol. Biochem., 2, 73 - 80.

Kolic N.U., Hrsak D., Kolar, A.B., Petric I., Stipicevic, S., Soulas, G., Martin-Laurent F. (2007), Combined metabolic activity with an atrazine-mineralizing community enriched from agrochemical factory soil. Int. Biodet. Biodeg., 60, 299-307.

Kross, B.C., Vergara, A., Raue, L.E. (1992), Toxicity assessment of atrazine, alachlor, and carbofuran and their respective environmental metabolites using Microtox. J. Toxicol. Environ. Health, 37, 149-59.

Ma, J., Wang, S., Wang, P., Ma, L., Chen, X., XU, R. (2006), Toxicity assessment of 40 herbicides to the green alga Raphidocelis subcapitata. Ecotoxicol. Environ. Saf., 63, 456-462.
Mandelbaum, R.T., Allan, D.L., Wackett, L.P. (1995), Isolation and characterization of a Pseudomonas sp. that mineralizes the s-triazine herbicide atrazine. Appl. Environ. Microbiol., 61, 1451 - 1457.

Martinez, B., Tomkins, J., Wackett, R., Wing, R. and Sadowsky, M.J. (2001), Complete nucleotide sequence and organization of the atrazine catabolic plasmid pADP-1 from Pseudomonas sp. strain ADP. J. Bacteriol., 183, 5684-5697.

Masaphy, S., Levanon, D., Vaya, J., Henis, Y. (1993), Isolation and characterization of a novel atrazine metabolite produced by the Fungus Pleurotus pulmonarius, 2-chloro-4-ethylamino-6-(1hydroxyisopropyl) amino 1,3,5-triazine. Appl. Environ. Microbiol., 59, 4342-4346.

Masaphy, S., Levanon, D., Henis, Y. (1996a), Degradation of atrazine by the lignocellulolytic fungus Pleurotus pulmonarius during solid - state fermentation. Biores. Technol., 56, 207 - 214.

Masaphy. S., Hrnis, Y., Levanon, D. (1996b), Manganese-enhaced biotransformation of atrazine by the white rot fungus Pleurotus pulmonarius and its correlation with oxidation activity. Appl. Environ. Microbiol., 2, 3587-3593.

Mougin C., Laugero C., Asther M., Dubroca J., Frasse P., Asther M. (1994), Biotransformation of the herbicide atrazine by the white rot fungus Phanerochaete chrysosporium. Appl. Environ. Microbiol., 60, 705-708.

Murphy, M.B., Hecker, M., Coady, K.K., Tompsett, A.R., Jones, P.D., Preez, L.H.D., Everson, G.J., Solomon, K.R., CARR, J.A., Smith, E.E., Kendall, R.J., Kraak, V.D., Giesy, J.P. (2006), Atrazine concentrations, gonodal gross morphology and histology in ranid frogs collected in Michigan agricultural areas. Aquat. Toxicol., 76, 230 - 245.

Neumann, G., Teras, R., Monson, L., Kivisaar, M., Schauer, F. and Heipieper, H.J. (2004), Simultaneous degradation of atrazine and phenol by Pseudomonas sp. strain ADP: Effects of toxicity and adaptation. Appl. Environ. Microbiol., 70, 1907-1912.

Ostrofsky, E.B., Robinson, J.B., Traina, S.J., Tuovinen, O.H. (2002), Analysis of atrazine-degrading microbial communities in soils using most-probablenumber enumeration, DNA hybridization, and inhibitors. Soil Biol. Biochem., 34, 1449-1459.

Parra, S., Stanca, S. E., Guasaquillo, Thanpi, K. R. (2004), Photocatalytic degradation of atrazine using suspended and supported $\mathrm{TiO}_{2}$. Appl. Catalysis B: Environ., 51, 107-116.

Perumbakkam, S., Hess, T.F. and Crawford, R. L. (2006) A bioremediation approach using natural transformation in pure-culture and mixed-population biofilms. Biodeg., 17, 545-557. 
Piutti, S., Semon, E., Landry, D., Hartmann, A., Dousset, S., Lichtfouse, E., Topp, E., Soulas, G., Martin-Laurent, F. (2003), Isolation and characterization of Nocardioides sp. SP12, an atrazine-degrading bacterial strain possessing the gene $\operatorname{trz} N$ from bulk-and maize rhizosphere soil. FEMS Microbiol. Lett., 221, 111 - 117.

Radosevich, M., Traina, S.J., Tuovinen, O.H. (1989), Biodegradation of atrazine in surface soils and subsurface sediments collected from an agricultural research farm. Biodeg., 7, 137 - 149.

Reddy, C.A. (1995), The potential for white-rot fungi in the treatment of pollutants. Curr. Opin. Biotechnol., 6, $320-328$.

Rhine, E.D., Fuhrmann, J.J., Radosevich, M. (2003), Microbial community responses to atrazine exposure and nutrient availability: linking degradation capacity to community structure. Microb. Ecol., 46, 145 - 160.

Ribeiro, A. B., Rodríguez-Maroto, J. M., Mateus, E.P., Gomes, H. (2005), Removal of organic contaminants from soils by an electrokinetic process: the case of atrazine. Experimental and modeling. Chemosph., 59, 1229-1239.

Rousseaux, S., A. Hartmann, and G. Soulas. (2001), Isolation and characterization of new gram-negative and gram-positive atrazine degrading bacteria from different French soils. FEMS Microbiol. Ecol., 36, 211-222.

Rousseaux,S., Hartmann, A., Lagacherie, B., Piutti,S., Andreux, F., Soulas, G. (2003), Inoculation of an atrazine-degrading strain, Chelatobacter heintzii Cit1, in four different soils: effects of different inoculum densities. Chemosph., 51, 569 - 576.

Sadowski, M.J., Tong, Z., Souza, M.L.D., Wackett, L.P. (1998), AtzC is a new member of the aminohydrolase protein superfamily and is homologous to other atrazine-metabolizing enzymes. J. Bacteriol., 180, 152 - 158.

Silva, E., Fialho, A.M., Sa-Correia I., Burns, R.G., Shaw, L.J. (2004), Combined bioaugmentation and biostimulation to cleanup soil contaminated with high concentrations of atrazine. Environ. Sci. Technol., 38, $632-637$.

Singh, N., Megharaj, M., Kookana, R. S., Naidu. R., Sethunathan, N. (2004b), Atrazine and simazine degradation in Pennisetum rhrizosphere. Chemosph., 56, 257-263.

Singh, P., Suri, C.R., Cameotra, S.S. (2004a), Isolation of a member of Acinetobacter species involved in atrazine degradation. Bioch. Bioph. Res. Comm. 317, $697-702$.

Smith, D., Alvey, S., Crowley D. E. (2005), Cooperative catabolic pathways within an atrazinedegrading enrichment culture isolated from soil. FEMS Microbiol. Ecol., 53, 265 - 273.

Stevens, J. T., Breckenridge, C.B., Wetzel, L.T., Gillis, J.H., Luempert III, L.G., Eldridge, J.C. (1994),
Hypothesis for mammary tumorigenesis in SpragueDawley rats exposed to certain triazine herbicides. $J$. Toxicol. Environ. Health, 43, 139-153.

Stoodley, P., Sauer, K., Davis, D.G. and Costerton, J.W. (2002), Biofilms as acomplex differentiated communities. Ann. Rev. Microbiol., 56, 187-209.

Strong, L.C., Tavish, H.M., Sadowsky, M.J., Wackett, L.P. (2000), Field-scale remediation of atrazine contaminated soil using recombinant Escherichia coli expressing atrazine chlorohydrolase. Environ. Microbiol., 2, 91-98.

Topp, E., H. Zhu, S. M. Nour, S. Houot, M. Lewis, and D. Cuppels (2000), Characterization of an atrazinedegrading Pseudaminobacter sp. isolated from Canadian and French agricultural soils. Appl. Environ. Microbiol., 66, 2773-2782.

U.S.EPA Office of Pesticide Programs Health Effects Division (2002). Grouping of Triazines Based on a Common Mechanism of Toxicity - Discusses the available evidence for determining if a common mechanism of toxicity exists among certain triazine containing pesticides. Available at: <http: //www.epa.gov/pesticides/cumulative/triazines/triazin es/triazinescommonmrch.pdf >. Access: 09 June 2006.

Vaishampayan, P.A., Kanekar, P.P., Dhakephalkar, P.K. (2007), Isolation and characterization of Arthrobacter sp. strain MCM B-436, an atrazinedegrading bacterium, from rhrizospheric soil. Biodet. Biodeg., 60, 273-278.

Vargha, M., Takats, Z., Márialigeti K . (2005), Degradation of atrazine in a laboratory scale model system with Danube river sediment. Wat. Res., 39, $1560-1568$.

von Wallbrunn, A., Richnow, H. H., Newman, G., Meinhardt, F. and Heipieper, H.J. (2003), Mechanism of cis-trans isomerization of unsatured fatty acids in Pseudomonas putida. J. Bacteriol., 185, 1730-1733.

Wackett, L. P., Sadowsky, M. J., Martinez, B., Shapir, N. (2002), Biodegradation of atrazine and related striazine compounds: from enzymes to field studies. Appl. Microbiol. Biotechnol., 58, 39- 45.

Weiner, J. A., De Lorenzo, M.E. and Fulton, M.H. (2004), Relationship between uptake capacity and differential toxicity of the herbicide atrazine in selected microalgal species. Aquat. Toxicol., 68, 121128.

Yassir, A., Rieu, C., Soulas, G. (1998), Microbial Ndealkylation of atrazine: Effect of exogeneous organic substrates and behaviour of the soil microflora. Pest. Sci., 54, 75-82.

Received: August 24, 2007; Revised: May 27, 2008; Accepted: July 28, 2009. 